\title{
Matematik Öğretmenlerinin Sonsuzluk, Belirsizlik ve Tanımsızlık Kavramlarına ilişkin Öğretimsel Açıklamaları
}

\author{
Nur SIRMACI, Yrd. Doç. Dr., Atatürk Üniversitesi, Kazım Karabekir Eğitim Fakültesi, Matematik ve Fen Bilimleri Eğitimi Bölümü, \\ nsirmaci@yahoo.com \\ Burçin GÖKKURT ÖZDEMIR, Yrd. Doç. Dr., Bartın Üniversitesi, Eğitim Fakültesi, Matematik ve Fen Bilimleri Eğitimi Bölümü, \\ gokkurtburcin@gmail.com
}

Özet: Bu çalışmanın amacı, matematik öğretmenlerinin sonsuzluk, belirsizlik ve tanımsızlık kavramlarına ilişkin öğretimsel açıklamalarını incelemektir. Bu doğrultuda, çalışma, 2015-2016 eğitimöğretim yılında ortaokulda ve lisede görev yapan toplam 13 matematik öğretmeni ile yürütülmüştür. Çalışmada nitel araştırma yaklaşımına dayalı durum çalışması yöntemi kullanılmıştır. Veri toplama aracı olarak, görüşme formu kullanılmıştır. Bu form iki bölümden oluşmaktadır. Formun ilk bölümünde, sonsuzluk, belirsizlik ve tanımsızlık kavramlarının ne olduğuna ilişkin 3 soru, ikinci bölümde ise sonsuzluk, belirsizlik ve tanımsızlık kavramlarını temsil eden 14 soru yer almaktadır. Verilerin analizinde ise nitel veri analizi tekniklerinden yararlanılmıştır. Bu kapsamda betimsel analiz tekniği kullanılmıştır. Çalışma sonunda, bazı öğretmenlerin sonsuzluk, belirsizlik ve tanımsızlık kavramlarını birbirlerinin yerine kullandıkları belirlenmiştir. Ayrıca bazı öğretmenlerin sembolik durumlara ilişkin gerekçelerinde önceden öğrendikleri kuralların etkili olduğu görülmüştür.

Anahtar Kelimeler: Sonsuzluk, belirsizlik, tanımsızlık, matematik öğretmeni

\section{Instructional Explanations of Mathematics Teachers' Regarding the Concepts of Infinity, Indeterminate and Undefined}

\begin{abstract}
The aim of this study is to reveal the instructional explanations of mathematics teachers on the concepts of infinity, indeterminate and undefined. In this regard, this study was conducted totally with 13 mathematics teachers working at secondary and high schools in the 2015-2016 academic year. The case study method, which is based on the qualitative research approach, was used in the study. The interview form was used in the study as the data collection tool. The form consisting of two parts was applied to teachers. In the first part of the form, there are three questions about what infinity, indeterminate and undefined concepts are, and in the second part there are fourteen questions representing the concepts of infinity, indeterminate and undefined. Qualitative data analysis techniques have been used in the analysis of data. In this content, descriptive analysis technique has been used. At the end of the study, it was found out that some teachers used the concepts of infinity, indeterminate and undefined instead of one another. Furthermore, it was observed that the rationale of some teachers of symbolic situations was affected by the rules they had previously learnt.
\end{abstract}

Key Words: Infinity, indeterminate, undefined, mathematics teachers 


\section{GíRiş}

Sonsuzluk yüzyıllardan beri ilgi odağı olan, sayı doğrusu gibi birçok matematik kavramları için temel kavramlardan biri (Kim, Sfard, \& Ferrini-Mundy, 2005) olduğuna göre bu kavramın aydınlatılması kaçınılmazdır. Ayrıca matematikteki tanımların önemli (Joshua, 2012) oluşu da bizi buna teşvik etmektedir. O halde, sonsuz kavramını tanımlamak için sade bir soruyla başlayalım. Sonsuz" $\infty "$ kavramı acaba sayı mıdır? Sorunun cevabını aşağıdaki cümlelerle vermeye çalışalım. $\times$, artı sayılardan sıfıra yaklaştığında $\frac{1}{x}+\infty$ 'a gider; $\times$, eksi sayılardan sıfıra yaklaştığında $\frac{1}{x} \quad-\infty$ 'a gider; $\infty$ işareti sonsuz olarak okunur ama herhangi bir gerçel sayıyı göstermez (Alev, Beler, \& Çakır, 1986). + $+\infty$ ve $-\infty$ birer sayı değil sadece semboldürler. $+\infty$ her pozitif sayıdan daha büyük ; $-\infty$, her negatif sayıdan daha küçük olan birer "büyüklük" olarak düşünülür (Kadıŏlu \& Kamali, 2009). Dikkat edilirse bunlar bir kavramın tanım ve tarifinin aynı olmadığının(Konyalıoğlu,2015) bir göstergesidir.

Bu açıklamalardan sonra sonsuzu sayı olarak kullanmanın hatalı olacağı anlaşılabilir. 0

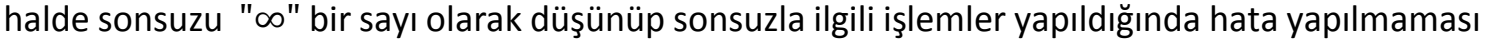
ya da sonsuz kavramını içeren kavramların yanlış olarak öğrenilmemesi gerekmektedir. Çünkü öğrenciler yeni matematiksel kavramlar öğrendiklerinde ya da öğrendiklerinin üzerine yeni bir şeyler koyduklarında önceki öğrendikleriyle ilişki kurmak zorundadırlar (Juter, 2005). $+\infty$ ve $-\infty$ birer sayı olmadıkları halde bunlarla ilgili işlemler tanımlanmıştır. Örneğin, a $x(+\infty)=+\infty(a>0$ ise). Gösterim kolaylığı olsun diye verilen a $x(+\infty)=+\infty$ ( $\mathrm{a}>0$ ise) gibi ifadeler aslında bir limit işleminin sonucudur. $+\infty$ ve $-\infty$ ile ilgili bazı işlemlerin ise belli bir tek değeri olamaz. Bunlar belirsizlik olarak adlandırılır(Kadıoğlu \& Kamali, 2009). Belirsiz halleri limit kavramının özel halleridir (Çekmez, 2016). Bir $f$ fonksiyonunun $x=a$ noktasındaki limiti araştırılırken, belirsiz şekiller denilen $\frac{0}{0}, \frac{\infty}{\infty}, \infty-\infty, 0 . \infty, 0^{0}, \infty^{0}, 1^{\infty}$ ifadelerle karşımıza çıkarlar (Balcı, 2010). Bunlara benzeyen $\infty+\infty,-\infty-\infty, 0^{+\infty}, 0^{-\infty}$ ifadeleri ise belirsizlik değildir. Bunlar için Kadıoğlu ve Kamali (2009), $\infty+\infty \rightarrow+\infty, \quad-\infty \quad-\infty \rightarrow-\infty, 0^{+\infty} \rightarrow 0,0^{-\infty} \rightarrow+\infty$ olduğunu ifade etmişlerdir.

Sonsuz kavramı ve belirsizlik arasındaki ilişkiler bu şekilde açıklandığına göre araştırmanın diğer bir konusu olan "Tanımsızlık" kavramı şu şekilde açıklanabilir. Sayılarla işlem yaparken dikkat edilmesi gereken en önemli nokta, sıfırdan farklı bir sayının sıfır ile bölünemeyeceğidir. Matematikte sıfırdan farklı bir sayının sıfır ile bölümü tanımsızdır. Çünkü, $a \neq 0$ olmak üzere $\frac{a}{0}$ tanımlı olsaydı $\frac{a}{0}=$ c olacak şekilde bir c reel sayısı bulunurdu. Bu durumda a=0.c, yani a=0 olurdu. Bu da $a \neq 0$ oluşuyla çelişir. O halde, sıfırdan farklı bir sayıyı sıfır ile bölmenin tanımlı olmayacağı aşikârdır (Kadıoğlu \& Kamali, 2009; Özmantar \& Bozkurt, 2013). Bu açıklamalardan görüldüğü üzere, sonsuzluk, belirsizlik ve tanımsızlık kavramları matematikte karşılaşılan kavramlar arasında yer almaktadır. Yapılan çalışmalar da, öğrencilerin sonsuzluk, belirsizlik ve tanımsızlık kavramlarını anlamlandırmada güçlük çektiklerini ve pek çok kavram yanılgısına sahip olduklarını göstermektedir (Çelik \& Akşan, 2013). Ayrıca ilgili literatür özellikle bu kavramlardan tanımsızlık ve belirsizlik ifadelerinin birbirlerinin yerine kullanıldığını göstermektedir (Baştürk \& Dönmez, 2011; Jaffar \& Dindyal, 2011). Bu kapsamda, bu iki kavram arasındaki farkın net olarak bilinmediği ve ayırt edilemediği söylenebilir.

Bu durum, öğretmenlerin bu kavramlara ilişkin anlamalarının araştırılması gerekliliğini ortaya koymaktadır. Çünkü öğretmen okulda öğrenmeyi düzenlemede ve şekillendirmede önemli rol oynayarak (Zikre \& Eu, 2016) bu sorumluluğu yerine getirmektedir. Öğretmenin öğrenmeyi yönlendirmede yardımcılarından biri konu alan bilgisidir (Shirvani, 2015). Çıkarımcı doğasından dolayı matematik, temeldeki birincil fikirlere, aksiyomlara ve tanımlara dayandığı (Narlı \& Narlı, 2013), aksiyomları ve tanımları bilme ve bunları kullanabilme matematik 
öğretiminde odak noktaları olduğu (Konyalığlu \& Gedik) için matematik öğretmeni bu bilgileri derinlemesine bilmelidir.

Öğretmenlerin sahip oldukları alan bilgisinin öğretimlerini etkilediği (Gökkurt, 2014) göz önünde bulundurulursa, öğretmenin konular arasında bağlantı kuramaması, kavramları yanlış öğrenmesi ve buna bağı olarak yanlış öğretmesi durumunda öğretim boyunca kavram yanılgılarına sahip olmalarına neden olabilir (Baştürk \& Dönmez, 2011). Bu durum da öğretmenlerin öğretim gerçekleştirdikleri öğrencilerin bu kavramlara ilişkin hata yapmalarına ya da kavram yanılgısına düşmelerine neden olabilir.

İlgili alanyazın incelendiğinde, bu kavramlar üzerine yapılan çalışmaların genellikle öğrenciler (Aztekin, 2008; Ervynck, 1994; Reys \& Grouws, 1975; Singer \& Voica, 2007) ve öğretmen adayları (Aztekin, Arikan, \& Sriraman, 2010; Crespo \& Cynthia, 2006; Çelik \& Akşan, 2013) ile yürütüldüğü dikkat çekmektedir. Öğretmenlerin bu kavramlara ilişkin anlamalarını inceleyen sınırlı sayıda çalışmaya (Cankoy, 2010) rastlandığı görülmektedir. Oysa bu kavramların öğretiminde bizzat rol oynayan öğretmenlerin bu kavramlara ilişkin alan bilgilerinin araştırılması önem arz etmektedir. Bu doğrultuda çalışmada matematik öğretmenlerinin sonsuzluk, belirsizlik ve tanımsızlık kavramlarına ilişkin anlamaları detaylı olarak incelenmiştir.

\section{YÖNTEM}

Bu çalışmada öğretmenlerin sonsuzluk, belirsizlik ve tanımsızlık kavramlarına ilişkin anlamaları derinlemesine incelendiğinden çalışmada nitel yaklaşım esas alınmış ve durum çalışması yöntemi kullanılmıştır. Durum çalışması, bir durumu, ilişkiyi, olayı ya da süreci, sınırlı sayıda örneklem ile her yönüyle inceler (McMillian \& Schumacher, 2010). Durum çalışmasının pek çok araştırma yönteminden ayırıcı özelliği eğitimin çeşitli konularını anlamada özellikle, ne, nasıl ve niçin soruları yöneltildiğinde tercih edilen bir yöntem olmasıdır (Çepni, 2012). Bu çalışmada sınırı örneklem seçilmesi ve öğretmenlerin sonsuzluk belirsizlik ve tanımsızlık kavramlarına ilişkin öğretimsel açıklamalarının detaylı incelenmesinden dolayı bu yöntem tercih edilmiştir.

\section{1 Çalışma Grubu}

Araştırmanın çalışma grubunu bir ildeki farklı ortaokullarda ve liselerde görev yapan 13 matematik öğretmeni oluşturmaktadır. Çalışma grubuna hem ortaokul hem de lisede görev yapan öğretmenlerin seçilmesinin nedeni olarak veri çeşitliliği yönünden zengin veri elde etmek ve her iki grubun da lisans döneminde sonsuzluk, belirsizlik ve tanımsızlık kavramlarını öğrenmiş olmaları gösterilebilir. Çalışma grubundaki öğretmenlerin kimliklerini gizli tutmak amacıyla lisede görev yapan matematik öğretmenlerine $\mathrm{L}_{1} \ldots \mathrm{L}_{6}$, ortaokulda görev yapan matematik öğretmenlerine ise $\mathrm{O}_{1} \ldots \mathrm{O}_{7}$ şeklinde kodlar verilmiştir. Çalışma grubundaki öğretmenlerin seçiminde zengin veri elde edileceği düşüncesiyle amaçlı örnekleme yöntemi kullanılmıştır. Bu öğretmenlerin demografik özellikleri Tablo 1'de verilmiştir.

Tablo 1

Öğretmenlerin Demografik Özellikleri

\begin{tabular}{cccc}
\hline ÖK & Bay & Bayan & Mesleki Kıdem \\
\hline $\mathrm{L}_{1}$ & $\checkmark$ & 22 \\
\hline $\mathrm{L}_{2}$ & $\checkmark$ & 3 \\
\hline $\mathrm{L}_{3}$ & $\checkmark$ & 31 \\
\hline $\mathrm{L}_{4}$ & $\checkmark$ & 15 \\
\hline
\end{tabular}




\begin{tabular}{lccc}
\hline $\mathrm{L}_{5}$ & $\checkmark$ & & 17 \\
\hline $\mathrm{L}_{6}$ & & $\checkmark$ & 5 \\
\hline $\mathbf{O}_{1}$ & $\checkmark$ & $\checkmark$ & 7 \\
\hline $\mathbf{O}_{2}$ & & & 2 \\
\hline $\mathbf{O}_{3}$ & $\checkmark$ & $\checkmark$ & 8 \\
\hline $\mathbf{O}_{4}$ & & $\checkmark$ & 27 \\
\hline $\mathbf{O}_{5}$ & & & 8 \\
\hline $\mathbf{O}_{6}$ & $\checkmark$ & & 3 \\
\hline $0_{7}$ & $\checkmark$ & & 30 \\
\hline
\end{tabular}

ÖK: Öğretmen Kodları

\subsection{Veri Toplama Araçları}

Veri toplama aracının hazırlanmasında Çelik ve Akşan (2013)'ın iki bölümden oluşan 12 sorunun yer aldığı form ile araştırmacıların hazırlamış olduğu 5 soru kullanılmıştır. Çelik ve Akşan (2013)'ın hazırladıkları formun ilk bölümünde sonsuzluk, belirsizlik ve tanımsızlık kavramlarının ne olduğuna ilişkin üç soru, ikinci bölümde ise sonsuzluk, belirsizlik ve tanımsızlık kavramlarını temsil eden dokuz soru yer almaktadır. İkinci bölüme araştırmacı tarafından öğretmenlerin veya öğretmen adaylarının sık karşılaştıkları belirsizlik ve sonsuzluk kavramlarını temsil eden 5 durum daha eklenmiştir. Bu beş durumun çalışmanın amacına uygun olup olmaması konusunda, alanında uzman bir öğretim üyesinin görüşlerinden faydalanılmıştır. Ayrıca çalışmanın geçerliği ve güvenirliği için iki matematik öğretmeni ile görüşme yapılarak pilot uygulama yapılmıştır. Pilot uygulamada öğretmenler, formun ikinci bölümünde sonsuzluk, belirsizlik ve tanımsızlık kavramlarını temsil eden 14 durum hakkında sonsuz, belirsiz ya da tanımsız şeklinde yüzeysel cevaplar vermişler ancak bu durumların neden sonsuz, belirsiz ya da tanımsız olduğu konusunda herhangi bir açıklamada bulunmamışlardır. Ayrıca pilot uygulamada bir öğretmenin, verilen bazı durumların bu üç kavramı (sonsuz, belirsiz, tanımsız) temsil etmediğini ifade ederek bazı durumların 0 ya da 1 olduğunu dile getirdiği ancak başka seçenek olmadığı için bu üç kavramdan rastgele birini işaretlediği görülmüştür. Dolayısıyla asıl uygulamadan önce bu 14 durumun yanına "Nedeni" şeklinde yönerge eklenerek öğretmenlerin verilen durumların neden sonsuz, belirsiz ya da tanımsız olduğunu belirtmeleri istenmiştir. Bunun yanında sonsuz, belirsiz ve tanımsız ifadelerinin yanına [Hiçbiri (Bu üç kavramın dışındaysa sonucun ne olduğunu lütfen belirtiniz)] ifadesi eklenerek veri toplama aracının ikinci bölümüne Tablo 2'deki gibi son şekli verilmiştir

Tablo 2

Veri toplama aracının ikinci bölümünde yer alan sorular

\begin{tabular}{|c|c|c|c|c|c|}
\hline $\begin{array}{l}\text { 2. Aşağıda v } \\
\text { nedenini be }\end{array}$ & $\begin{array}{l}\text { ilen sem } \\
\text { terek aç }\end{array}$ & $\begin{array}{l}\text { lik göste } \\
\text { ayınız. }\end{array}$ & ler sizin & ne anlam ifade etme & Cevabır \\
\hline $\begin{array}{l}\text { Sembolik } \\
\text { gösterimler }\end{array}$ & Sonsuz & Belirsiz & Tanımsız & $\begin{array}{l}\text { Hiçbiri } \\
\text { (Bunların dışındaysa } \\
\text { sonucun ne olduğunu } \\
\text { lütfen belirtiniz. }\end{array}$ & Nedeni \\
\hline $\begin{array}{l}\text { a) } \infty+\infty \\
\text { b) } 1^{\infty} \\
\text { c) } \infty . \infty \\
\text { d) } \infty n\end{array}$ & & & & & \\
\hline
\end{tabular}




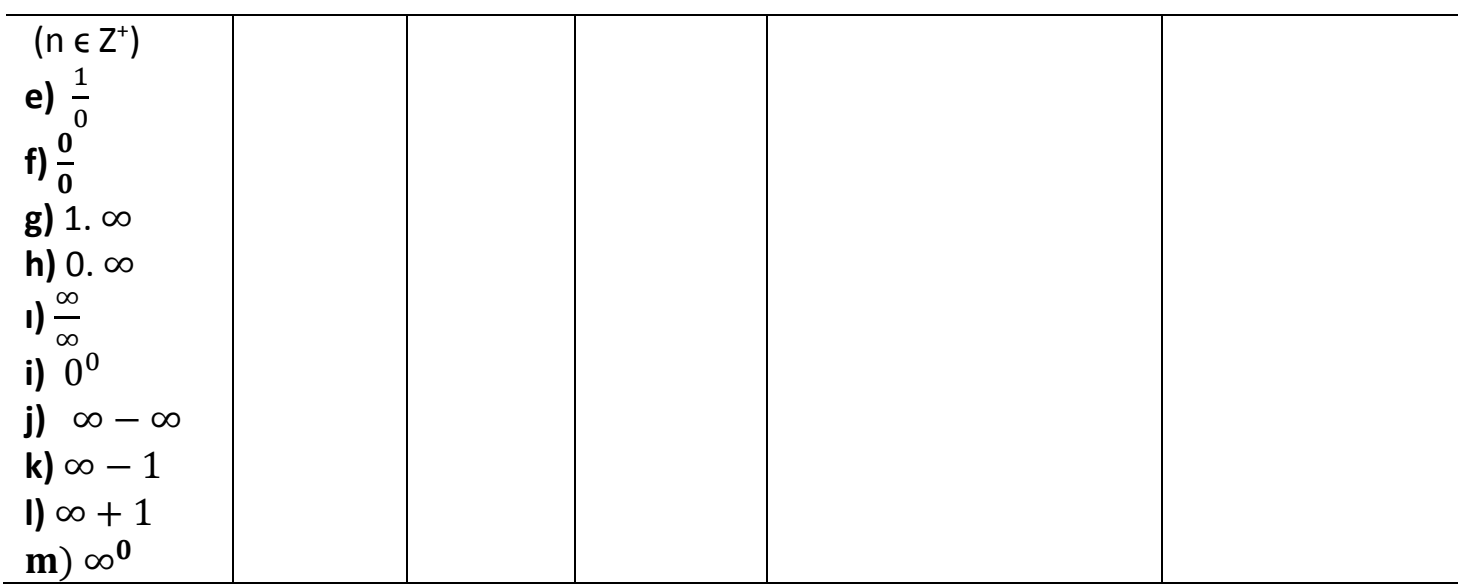

\subsection{Verilerin Analizi}

Verilerin analizinde nitel veri analizi tekniklerinden betimsel analiz kullanılmıştır. Betimsel analizde veriler, önceden belirlenen kategorilere ve kodlara göre düzenlenir (Yıldırım \& Şimşek, 2013). Bu kapsamda, öğretmenlerin sonsuzluk, belirsizlik ve tanımsızlık durumlarını temsil eden gösterimine ilişkin cevaplarında Gökkurt, Şahin ve Soylu (2012)'nun cevap kategorileri olan doğru, kısmen doğru, yanlış ve boş kategorileri dikkate alınmıştır. Öğretmenlerin sonsuzluk, belirsizlik ve tanımsızlık kavramlarına ilişkin tanımlarında Maria, Thanasia, Katerina, Constantinos ve George (2009)'un kodları ile Özmantar ve Bozkurt (2013)'un belirsizlik ve tanımsızlık için kullandığı terimler kodlar olarak kullanılmıştır. Bu kavramların tanımları literatürde tartışıımakta ve formal tanımları hakkında fikir birliği yoktur. $\mathrm{Bu}$ nedenle öğretmenlerin bu kavramlara ilişkin tanımlarının doğru veya yanlış olarak değerlendirilmesi yerine, bu kavramların onlar için ne anlam ifade ettiği üzerinde durulmuştur. Bu kodlar Tablo 3'te sunulmuştur.

Tablo 3

Sonsuzluk, Belirsizlik ve Tanımsızlık Kavramlarının Tanımlarında Kullanılan Kodlar

\begin{tabular}{lll}
\hline \multirow{2}{*}{$\begin{array}{ll}\text { Oaria vd. (2009) } \\
\text { (2013) }\end{array}$} & Sonsuzluk & Süreç \\
\cline { 2 - 2 } & & Obje \\
\cline { 2 - 3 } & Belirsizlik & Belirsiz değer \\
\cline { 2 - 3 } & Tanımsızlık & Belirsiz durum/form \\
\cline { 2 - 2 } & & Tanımsız değer \\
\hline
\end{tabular}

Çalışmanın güvenirliği için, veriler iki araştırmacı tarafından bu kodlara göre analiz edilmiş ve uyuşum yüzdesi Miles ve Huberman (1994)'a göre \%97 olarak hesaplanmıştır. Geriye kalan \%3'lük farklııı için araştırmacılar biraraya gelerek fikir birliğine varmışlardır.

\section{BULGULAR VE YORUM}

Çalışmadan elde edilen bulgular, sonsuzluk, belirsizlik ve tanımsızlık kavramlarına ilişkin bulgular şeklinde üç alt başlık halinde sunulmuştur. 


\subsection{Sonsuzluk Kavramının Tanımı ve Sonsuzluk Kavramını Temsil Eden Gösterimlere ìlişkin Bulgular}

Tablo 4

Matematik Öğretmenlerinin Sonsuzluk Kavramının Tanımına iliş̧kin Verdikleri Cevaplar

\begin{tabular}{lll}
\hline Sonsuzluk & Ök & Örnek Açıklamalar \\
\hline Süreç & $\mathrm{L}_{1}$ & Sonuç sonsuza kadar gider, işlem sonucu hiç bitmez $\left(\mathrm{L}_{1}\right)$ \\
\hline Obje & $\mathrm{L}_{2}, \mathrm{~L}_{4}$, & Sonsuzluk, sonsuzluğu ifade etmek için kullanılan \\
& $\mathrm{L}_{5} \mathrm{~L}_{6}, \mathrm{O}_{1}, \mathrm{O}_{2}, \mathrm{O}_{3}$, & matematiksel semboldür $\left(\mathrm{O}_{3}\right)$ \\
& $\mathrm{O}_{4}, \mathrm{O}_{5}, \mathrm{O}_{6}, \mathrm{O}_{7}$ & $\begin{array}{l}\text { Mevcut ölçü birimleriyle ifade edilemeyecek büyüklükler için } \\
\text { kullanılan bir semboldür }\left(\mathrm{L}_{4}\right)\end{array}$ \\
& & $\begin{array}{l}\text { Bir kümenin eleman sayısı sayılamaz çoklukta ise o küme } \\
\text { sonsuzdur }\left(\mathrm{L}_{2}\right)\end{array}$ \\
& & Tanım yapamıyorum $\left(\mathrm{L}_{3}\right)$
\end{tabular}

ÖK: Öğretmen Kodları

Tablo 4 incelendiğinde, öğretmenlerin çoğunun sonsuzluk kavramını obje (sembol, küme vb.) olarak tanımladıkları görülmektedir. Sadece bir öğretmen sonsuzluğu süreç olarak ifade eden tanıma yer vermiştir.

Tablo 5

Matematik Öğretmenlerinin Sonsuzluk Kavramını Temsil Eden Durumlara iliş̧kin Verdikleri Cevaplar

\begin{tabular}{|c|c|c|c|c|c|}
\hline & $\begin{array}{l}\text { Sembolik } \\
\text { Gösterimler }\end{array}$ & Doğru & $\begin{array}{l}\text { Kısmen } \\
\text { Doğru }\end{array}$ & Yanlış & Boş \\
\hline \multirow{6}{*}{ 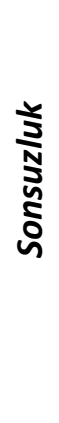 } & $\infty+\infty$ & $\mathrm{L}_{1}{ }^{*}, \mathrm{~L}_{2}, \mathrm{~L}_{4}, \mathrm{~L}_{5}{ }^{*}, \mathrm{~L}_{6}{ }^{*}, \mathrm{O}_{1}, \mathrm{O}_{2}, \mathrm{O}_{4}{ }^{*}, \mathrm{O}_{5}{ }^{*}, \mathrm{O}_{6}{ }^{*}$ & $\mathrm{~L}_{3}^{*}$ & $\mathrm{O}_{3,} \mathrm{O}_{7}{ }^{*}$ & \\
\hline & $\infty . \infty$ & $\mathrm{L}_{1}, \mathrm{~L}_{2}{ }^{*}, \mathrm{~L}_{4}, \mathrm{~L}_{5}, \mathrm{~L}_{6}{ }^{*}, \mathrm{O}_{1}, \mathrm{O}_{2}, \mathrm{O}_{4}, \mathrm{O}_{5}, \mathrm{O}_{6}$ & $\mathrm{~L}_{3}$ & $\mathrm{O}_{3}, \mathrm{O}_{7}$ & \\
\hline & $\infty^{n}\left(n \in Z^{+}\right)$ & $\mathrm{L}_{1}, \mathrm{~L}_{2}{ }^{*}, \mathrm{~L}_{3}, \mathrm{~L}_{4}, \mathrm{~L}_{5}, \mathrm{~L}_{6}{ }^{*}, \mathrm{O}_{1}, \mathrm{O}_{2}, \mathrm{O}_{3}, \mathrm{O}_{4}{ }^{*}, \mathrm{O}_{5}, \mathrm{O}_{6}{ }^{*}, \mathrm{O}_{7}{ }^{*}$ & & & \\
\hline & $1 . \infty$ & $\mathrm{L}_{1}, \mathrm{~L}_{2}{ }^{*}, \mathrm{~L}_{3}, \mathrm{~L}_{5}, \mathrm{~L}_{6}{ }^{*}, \mathrm{O}_{1}, \mathrm{O}_{2}, \mathrm{O}_{3}, \mathrm{O}_{4}{ }^{*}, \mathrm{O}_{5}, \mathrm{O}_{6}{ }^{*}$ & & $\mathrm{~L}_{4}{ }^{*}, \mathrm{O}_{7}$ & \\
\hline & $\infty-1$ & $\mathrm{~L}_{2}{ }^{*}, \mathrm{~L}_{3}, \mathrm{~L}_{4}, \mathrm{~L}_{5}{ }^{*}, \mathrm{~L}_{6}{ }^{*}, \mathrm{O}_{1}, \mathrm{O}_{2}, \mathrm{O}_{3}, \mathrm{O}_{5}, \mathrm{O}_{6}{ }^{*}$ & & $\mathrm{~L}_{1}, \mathrm{O}_{4}, \mathrm{O}_{7}{ }^{*}$ & \\
\hline & $\infty+1$ & $\mathrm{~L}_{2}{ }^{*}, \mathrm{~L}_{3}, \mathrm{~L}_{4}, \mathrm{~L}_{5}{ }^{*}, \mathrm{~L}_{6}{ }^{*}, \mathrm{O}_{1}, \mathrm{O}_{2}, \mathrm{O}_{3}, \mathrm{O}_{5}, \mathrm{O}_{6}{ }^{*}$ & & $\mathrm{~L}_{1}, \mathrm{O}_{4}, \mathrm{O}_{7}{ }^{*}$ & \\
\hline
\end{tabular}

$\left({ }^{*}\right)$ simgesi olan katılımcılar, verdiği cevabın altında yatan nedene ilişkin açıklama yaparken, $\left({ }^{*}\right)$ simgesi olmayan katılımcılar ise, verdiği cevabın altında yatan nedene ilişkin açıklama yapmamıştır.

Tablo 5 incelendiğinde, öğretmenlerin tamamının $\infty^{n}$ 'nin neyi ifade ettiği sorusuna doğru yanıt verdikleri görülmektedir. Yapılan görüşmelerde $\infty^{n}$ gösterimini sonsuzluk olarak belirten öğretmenlerden bazıları, bu gösterimin neden sonsuz olduğuna ilişkin açıklama yaparken, bazıları $\left(\mathrm{L}_{1}, \mathrm{~L}_{3}, \mathrm{~L}_{4}, \mathrm{~L}_{5}, \mathrm{O}_{1}, \mathrm{O}_{2}, \mathrm{O}_{3}, \mathrm{O}_{5}\right)$ da herhangi bir açıklamada bulunamamışlardır. Bununla ilgili olarak aşağıda açıklama yapan öğretmenlerden alıntılar verilmiştir.

"Sonsuzun ne kadar kuvvetini alırsanız alın yine sonsuz olur $\left(\mathrm{L}_{6}, \mathrm{O}_{4}, \mathrm{O}_{6}\right)$ "

"Sayılamaz $\left(L_{2}\right)$ "

" $n \in Z^{+}$için $n$ yerine hangi sayının yazılacağı belli değildir. Dolayısıyla sonuç sonsuz $\operatorname{olur}\left(\mathrm{O}_{7}\right)$ " 
Öğretmenlerin açıklamalarına bakıldığında yüzeysel cevap verdikleri, sembolik gösterimin sözel ifadesiyle ilgili açıklama yaptıkları görülmektedir.

1. $\infty$ ifadesiyle ilgili bulgular incelendiğinde, iki öğretmenin hatalı cevap verdiği görülmektedir. íki öğretmenle yapılan görüşmelerde, $\mathrm{O}_{7}$ bu ifadeyi belirsiz olarak ifade ederken, $\mathrm{L}_{4}$ öğretmeni de sonucun 1 olduğunu belirtmiş̧ir. $\mathrm{O}_{7}$, verdiği cevabın gerekçesini yapamazken, $\mathrm{L}_{4}$ bu ifadenin neden 1 olduğunu aşağıdaki gibi açıklamıştır.

"Sonucun 1 olması gerekiyor. 1 hangi sayı ile çarpılırsa çarpılsın 1 sonucunu verir. Etkisiz eleman özelliğinden..."

Katılımcının bu açıklamasına dayalı olarak, etkisiz eleman özelliği ile yutan eleman özelliğini birbirine karıştırdığı söylenebilir. Çünkü 1 sayısı herhangi bir sayı ile çarpıldığı zaman sonuç, çarpıldığı sayıyı verir. Bu açıklamaya göre katılımcıdan beklenen cevap $\infty$ olmalıydı. Bu gösterimi doğru olarak yanıtlayan $\mathrm{O}_{4}$, bu gösterimin sonsuz olduğunu "1 çarpma işlemini etkilemediği için cevap sonsuzdur. 1 sayısı çarpma işlemine göre etkisiz eleman olduğu için 1'in etkisi yoktur" şeklinde doğru cevap vermiştir.

Doğru cevap veren diğer katılımcıların açıklamalarına bakıldığında ise, yedi öğretmen $\left(L_{1}, L_{3}, L_{5}, O_{1}, O_{2}, O_{3}, O_{5}\right)$ görüş bildirmemiş, iki öğretmen $\left(L_{2}, L_{6}\right)$ gösterimi aynen ifade eden "sonsuz ile bir sayısını çarptığımız zaman sonsuzdur, sayılamaz" şeklinde tekrarlı açıklamalar yapmışlardır. $\mathrm{O}_{6}$ öğretmeni de "sonsuzun çarpanları da sonsuzdur" şeklinde anlaşılır olmayan bir gerekçe öne sürmüştür.

Tablo 5'te $(\infty-1)$ ve $(\infty+1)$ gösterimleriyle ilgili bulgulara göre, 10 öğretmen verilen bu gösterimleri doğru olarak ifade etmişlerdir. Bu öğretmenlerden sadece dördü bu gösterimlerin neden sonsuz olduğuna ilişkin açıklamada bulunmuşlardır. Bu açıklamalar aşağıda sunulmuştur.

"Sonsuzdan 1 gibi herhangi bir sayıyı çıkardığımızda yine sayılamayacak çoklukta ya da büyüklükte bir sayı kalır. Benzer şekilde sonsuza 1 gibi herhangi bir sayıyı eklediğimizde yine sonsuz olur. 1 büyüklügüne etki etmez $\left(L_{5}, L_{6}, O_{6}\right)$ "

$$
\text { "Sayılamaz }\left(L_{2}\right) \text { " }
$$

Katılımcıların açıklamalarına bakıldığında, gösterimleri ifade eden benzer açıklamalar yaptıkları görülmektedir. Yanlış yapan katılımcıların cevapları incelendiğinde, üç öğretmen $\left(L_{1}, O_{4}, O_{7}\right),(\infty-1)$ ve $(\infty+1)$ gösterimlerini sonsuz olarak ifade etmeleri gerekirken, belirsiz olarak ifade ederek yanlış cevap vermişlerdir. Bu öğretmenlerden ikisi belirsiz olmasının altında yatan mantıksal gerekçe hakkında herhangi bir fikir belirtmezken, $\mathrm{O}_{7}$, mantıksal olmayan bir gerekçe öne sürmüştür. Katılımcının aşağıda verilen alıntısı bu açıklamayı desteklemektedir.

"-1 baz alınırsa sonuç -1 olur, $\infty$ alınırsa $\infty$ 'dan bir sayı çıkarılması yine sonsuz olur. Sonuç belirsizdir. Toplama işleminde de benzer şekilde..."

Katılımcıların $(\infty . \infty)$ ve $(\infty+\infty)$ için verdikleri cevaplar incelendiğinde, üç öğretmenin bu durumları sonsuz olarak ifade edemedikleri için doğru cevap veremedikleri görülmektedir. İi öğretmen bu gösterimleri belirsiz olarak ifade ederken, $L_{3}$ hem belirsiz, hem de sonsuz olarak ifade etmiştir. $L_{3}$ hem doğru, hem de yanlış cevap verdiği için cevabı kısmen doğru olarak değerlendirilmiştir. Katılımcılara bu gösterimlerin belirsiz olmasının altında yatan neden 
sorulduğunda, katılımcılar "Sonu olmayan, bilinmeyen olduğu için. Sonuç belli değil" gibi cevabı tekrar eden açıklamalar yapmışlardır. Görüşme esnasında, $L_{3}$ 'ün "Sonsuz, belirsiz ve tanımsız kavramlarını ögrencilerimize eş anlamlı olarak anlatıyoruz. Bu ifadeler sonsuz, bilinmeyen olduğu için de belirsiz diyebiliriz" demesi katılımcının bu iki kavramı eş değer tuttuğunu açıkça göstermektedir.

\section{ilişkin Bulgular}

\subsection{Belirsizlik Kavramının Tanımı ve Belirsizlik Kavramını Temsil Eden Gösterimlere}

Tablo 6

Matematik Öğretmenlerinin Belirsizlik Kavramının Tanımına ilişsin Verdikleri Cevaplar

\begin{tabular}{lll}
\hline Belirsizlik & ÖK & Örnek Açıklamalar \\
\hline Belirsiz Değer & $\mathrm{L}_{1}, \mathrm{~L}_{2}, \mathrm{~L}_{4}, \mathrm{~L}_{5}$, & Belirsizlik, verilen işlemde hangi sayının belli olmaması. Yani \\
& $\mathrm{O}_{1}, \mathrm{O}_{2}$, & birden fazla değerin sağlıyor olması denilebilir. Örneğin $\frac{0}{0}=x$ \\
& $\mathrm{O}_{3}, \mathrm{O}_{4}, \mathrm{O}_{6}$, & ifadesinde $0=0 . x$ ifadesinde x yerine birçok değer gelebilir $\left(\mathrm{L}_{6}\right)$ \\
& $\mathrm{L}_{6}$ & \\
& $\mathrm{O}_{7}$ & Limitte karşılaştığımız durumlardır. $L^{\prime}$ hospital kuralında \\
Belirsiz & & karşımıza çıkan durumlar. Örneğin $\frac{\infty}{\infty}$ belirsiz durumdur $\left(O_{7}\right)$ \\
Durum/Form & $\mathrm{L}_{3}, \mathrm{O}_{5}$ & Tanım yapamadım $\left(\mathrm{L}_{3}, O_{5}\right)$
\end{tabular}

ÖK: Öğretmen Kodları

Tablo 6 incelendiğinde, iki öğretmen dışında geriye kalan öğretmenlerin belirsizlik kavramını tanımlamaya çalıştıkları görülmektedir. Tanımlar incelendiğinde, bazı öğretmenlerin limitte karşılan belirsiz formlara yönelik tanımlar yaptığı, bazı öğretmenlerin de belirsiz ifadede $x$ değişkeninin değerini düşünerek belirsiz değere vurgu yaptıkları görülmektedir.

Tablo 7

Matematik Öğretmenlerinin Belirsizlik Kavramını Temsil Eden Durumlara ilişkin Verdikleri Cevaplar

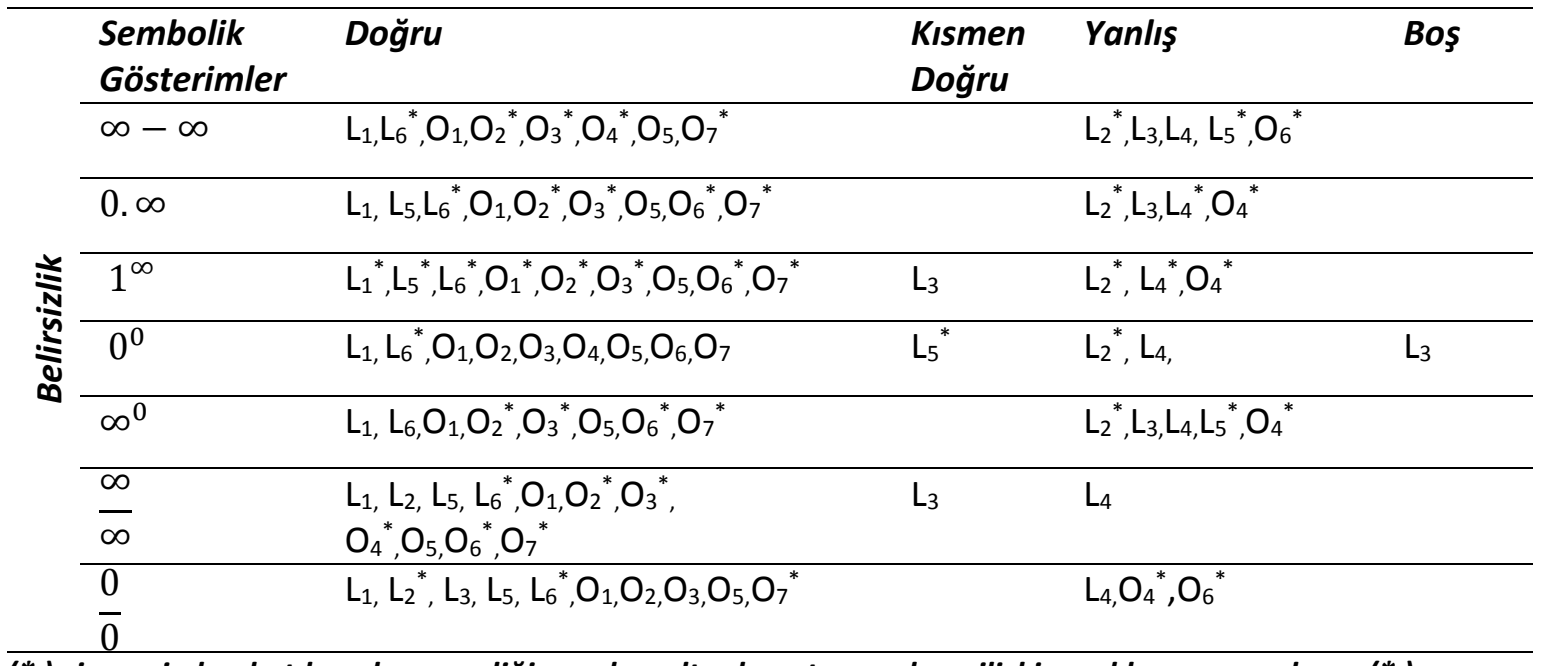

$\left(^{*}\right)$ simgesi olan katılımcılar, verdiği cevabın altında yatan nedene ilişkin açıklama yaparken, $\left({ }^{*}\right)$ simgesi olmayan katılımcılar, verdiği cevabın altında yatan nedene ilişkin açıklama yapmamıştır.

Tablo 7'ye göre matematik öğretmenlerinin çoğu belirsiz olan durumları doğru olarak ifade edebilmişlerdir. Belirsiz olan durumlara ilişkin gösterimler arasında en çok $\left(\infty^{0}\right)$ ve $(\infty-\infty)$ ifadesinde zorluk yaşarken, en az zorlandıkları gösterim $\left(\frac{\infty}{\infty}\right)$ olmuştur. 
$\left(\infty^{0}\right)$ belirsizliği ile ilgili öğretmenlerin açıklamaları incelendiğinde, doğru cevap veren sekiz öğretmenden yarısı $\left(\mathrm{O}_{2}, \mathrm{O}_{3}, \mathrm{O}_{6}, \mathrm{O}_{7}\right)$ belirsizliğin nedenine ilişkin açıklama yaparken, yarısı da $\left(L_{1}, L_{6}, O_{1}, O_{5}\right)$ hiçbir açıklama yapamamıştır. Açıklama yapan öğretmenlerden üçü belirsizliğin altında yatan mantıksal gerekçeyi doğru ifade ederken, $O_{6}$ da "Sonsuzun ne olduğu belirsiz olduğu için sonsuz belirsizdir" şeklinde yüzeysel cevap vermiştir. Mantıksal gerekçeyi doğru ifade eden öğretmenler, , sonucun neden belirsiz olduğunu verilen ifadeye $x$ diyerek her iki tarafın $\ln ^{\prime} n i$ alarak açıklamıştır. Bu öğretmenlerden $O_{7}$, biraz zorlansa da sonunda mantıksal gerekçesini ifade edebilmiştir. Katıımıını Şekil 1'de verilen yazılı cevabı bu durumu örneklendirmektedir.

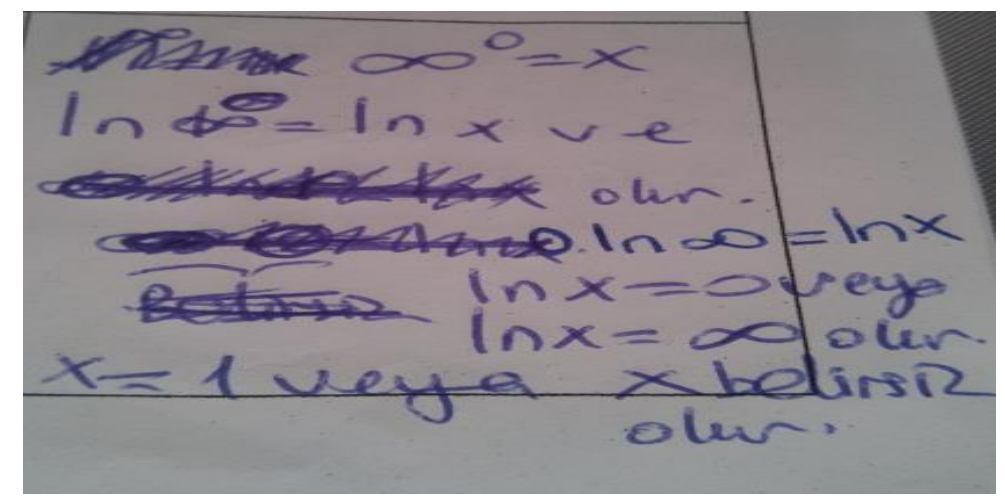

Şekil 1. $O_{7}$ ögretmeninin $\infty^{0}$ gösteriminin belirsiz olduğuna ilişkin cevabı

Yanlış cevap veren beş öğretmenin görüşme verileri incelendiğinde, üç öğretmen $\left(L_{3,}, L_{4}\right.$, $L_{5}$ ) bu gösterimin tanımsız olduğunu, iki öğretmen de $\left(L_{2}, O_{4}\right)$ sonucun 1 olduğunu ifade etmiştir. Sonucun 1 olmasını ifade eden katılımcılar kuvvetin sıfır olmasına bakarak gerekçesini açıklamışlardır. Aşağıda verilen alıntılar, bunu açıkça göstermektedir.

"Üstteki sıfır sonucu 1 yapar" $\left(L_{2}\right)$

\section{"Sıfır hariç bütün sayıların sıfırıncı kuvveti 1'dir" $\left(\mathrm{O}_{4}\right)$}

Katılımcıların açıklamalarına dayalı olarak, katııımıların sonsuzu sayı olarak algıladıkları görülmektedir. Yapılan görüşmelerde $(\infty-\infty)$ belirsizliği ile ilgili öğretmenlerin açıklamaları incelendiğinde, beş öğretmenin bu gösterimi bilemediği, $\mathrm{L}_{4}$ 'ün tanımsız, geriye kalan dört öğretmenin ise sonsuz olarak ifade ettikleri görülmüştür. $L_{4}$ verdiği cevabın gerekçesini ifade edemezken, diğer katılımcılar mantıklı olmayan açıklamalarda bulunmuşlardır. Bu açıklamaları temsil eden iki alıntıya yer verilmiştir.

"Sonsuzdur, sonunda çıkan sayının önemi yoktur" $\left(O_{6}\right)$

"Sonsuzlardan hangisinin büyük olduğunu bilemediğim için bir kavramdan ne kadar bir büyüklük çıkacağını bilmiyoruz." $\left(L_{5}\right)$

Yukarıdaki alıntılar dikkate alındığında, katıımcıların öne sürdükleri gerekçenin tutarlı olmadığı açıkça görülmektedir. Özellikle de $L_{5}^{\prime}$ in sonucun belli olmadığını ifade etmesine rağmen sonsuz olarak nitelendirmesi, katılımcının yaptığı açıklama ile verdiği cevabın çeliştiğini göstermektedir. Buna benzer açıklama yapan $\mathrm{L}_{6}$ ve $\mathrm{O}_{7}$ yaptıkları açıklamayla tutarlı cevap vererek bu gösterimin belirsiz olduğunu aşağıdaki gibi dile getirmişlerdir.

"Sayılamayacak çoklukta iki çokluğun biri diğerinden ne kadar büyük belli değildir." $\left(L_{6}\right)$ 
Bu açıklamalara dayalı olarak, katıımcılar sonsuzu sayı olarak düşünmüşler ve farklı büyüklükte sonsuzların olabileceğini belirtmişlerdir. Bununla ilgili olarak $\mathrm{O}_{2}$ öğretmenin bu gösterimin neden belirsiz olduğunu ifade eden yazılı cevabı Şekil 2'de aynen verilmiştir.

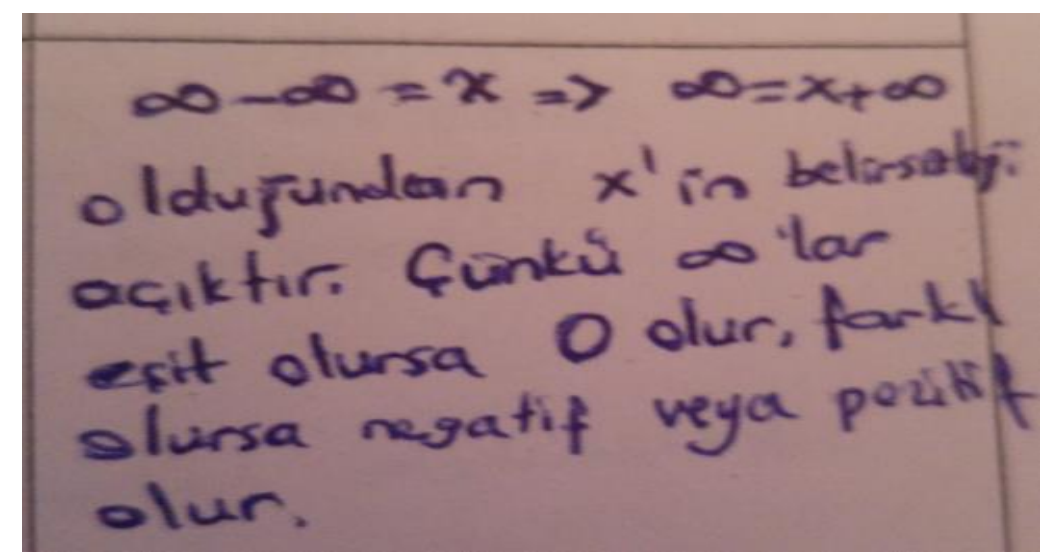

Şekil 2. $\mathrm{O}_{2}$ öğretmeninin $\infty-\infty$ gösteriminin belirsiz olduğuna ilişkin cevabı

$(0 . \infty)$ belirsizliği ile ilgili bulgular incelendiğinde, dokuz öğretmen bu gösterimin belirsiz olduğunu belirterek doğru cevap vermişlerdir. Dokuz öğretmenden dördü $\left(L_{1}, L_{5}, O_{1}, O_{5}\right)$ bu gösterimin neden belirsiz olduğunu açıklamazken, beş öğretmen açıklama yapabilmiştir. Bu açıklamalar detaylı incelendiğinde, üç öğretmen $\left(\mathrm{O}_{2}, \mathrm{O}_{3}, \mathrm{O}_{7}\right)$ sonucun ya sıfır ya da sonsuz olabileceğini ifade ederek doğru sayılabilecek mantıksal açıklama yapmışlardır. Bununla ilgili olarak, Şekil 3'te $\mathrm{O}_{7}^{\prime}$ nin yazılı açıklamasına yer verilmiştir.

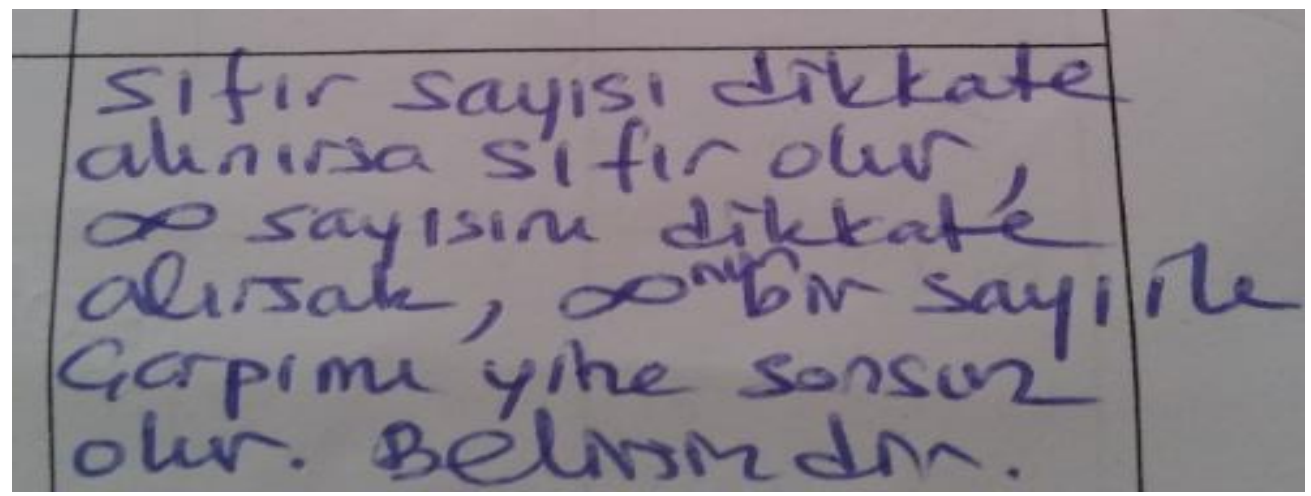

Şekil 3. $O_{7}$ ögretmeninin $0 . \infty$ gösteriminin belirsiz olduğuna ilişkin cevabı

Bu gösterimin belirsiz olduğunu ifade eden diğer öğretmenlerin açıklamalarına bakıldığında ise $L_{6}$ doğru sayılabilecek detaylı bir açıklama yaparken, $O_{6}$ mantıksal olmayan yüzeysel bir açıklama yapmıştır. Aşağıda verilen alıntılar, bu durumu desteklemektedir.

"0. $\infty=x$ olsun. Buradan $\infty=\frac{x}{0}$ sayı bölü sıfır sonsuz olur. Bu durumda $x$ yerine gelebilecek birden fazla sayı vardır. Belirli bir sayı yoktur. Bu nedenle sonuç belirsiz olur." ( $\left.L_{6}\right)$

" $\infty$ 'un belli olmamasından dolayı 0 ile çarpımı belirsizdir." $\left(O_{6}\right)$ 
Yanlış cevap veren öğretmenlerin açıklamaları dikkate alındığında, üç öğretmen $\left(L_{2}, L_{4}, O_{4}\right)$ sıfır, bir öğretmen $\left(L_{3}\right)$ de sonsuz cevabını vermiştir. Üç öğretmen, sıfırın çarpma işlemine göre yutan eleman özelliği gerekçesiyle sıfır cevabını verirken, $L_{3}$ sonsuzun büyüklüğüne vurgu yaparak cevabın sonsuz olacağını belirmiştir. Bu açıklamalardan yola çıkarak öğretmenlerin doğru gerekçeler öne sürmedikleri, üç öğretmenin $\infty, L_{3}$ 'ün de 0 sayısını dikkate almadığı söylenebilir. Öğretmenlerin $1^{\infty}$ ve $0^{0}$ için verdikleri cevaplara göre, dokuz öğretmen bu sembolik gösterimlerin belirsizlik durumunu ifade ettiklerini belirterek doğru cevap vermişlerdir. ỉki gösterimi karşılaştırdığımızda görüşme verilerinden öğretmenlerin $0^{0}$ ın neden belirsiz olduğunu ifade etmede, $1^{\infty}$ ' a göre oldukça zorlandıkları ve açıklama yapamadıkları görülmüştür. Bazı öğretmenler, doğru sayılabilecek " $0^{0}=x$ dersek her iki tarafın In'ni alalım. $\ln 0^{0}=\ln x$ olur..." şeklinde bir yol seçseler de açıklamasının sonunu getirememişlerdir. Oysa bu açıklamanın devamında belirsizlik durumu şu şekilde açıklanabilirdi:

$0^{0}=x$ dersek her iki tarafın In'ni alalım. $\operatorname{In} 0^{0}=\operatorname{In} x$ olur. In özelliğinden $0 . \operatorname{In} 0=\ln x$ olur. Buradan 0 sayısı göz önüne alınırsa $x=1$, In0 göz önüne alınırsa Ino tanımlı olmadığından $x$ değeri de belirsiz olur. Sonuç belli olmadığından bu gösterimin sonucu belirsizdir.

$1^{\infty}$ belirsizliği için benzer yolu seçen öğretmenler, yaptıkları açıklamanın devamını getirerek doğru sayılabilecek gerekçeler öne sürmüşlerdir. Bu yolu seçen üç öğretmenden $\left(\mathrm{O}_{2}, \mathrm{O}_{3}, \mathrm{O}_{7}\right)$ birinin yazılı açıklaması Şekil 4'te aynen verilmiştir.

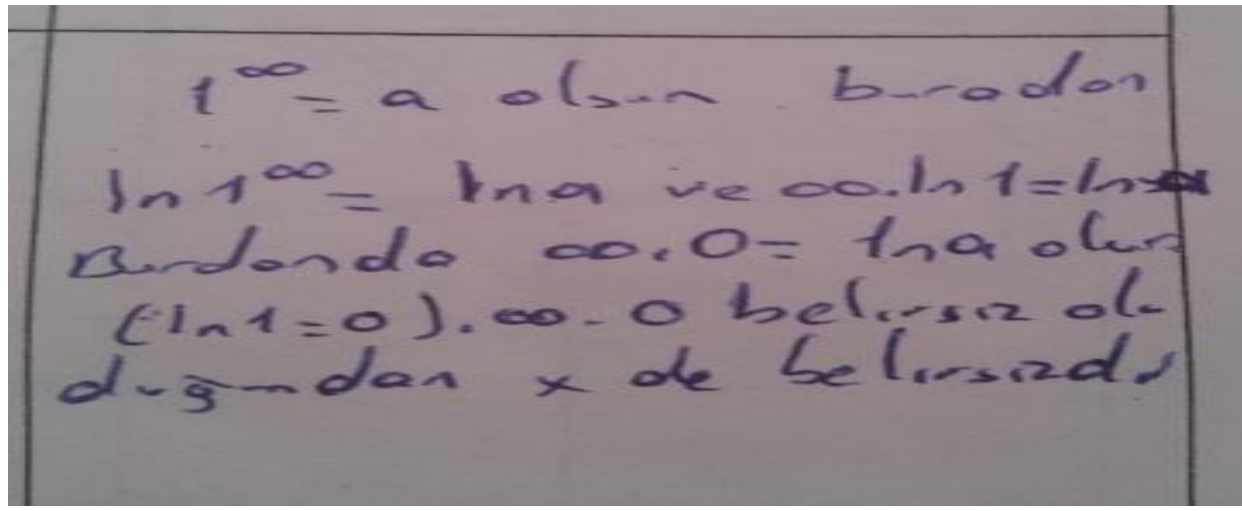

Şekil 4. $\mathrm{O}_{3}$ öğretmeninin $1^{\infty}$ gösteriminin belirsiz olduğuna ilişkin cevabı

Yapılan görüşmelerde, $L_{5}$ ve $L_{6}$ olan öğretmenler, görüşmede bu gösterimi derslerinde belirsizlik olarak verdiklerini ancak neden belirsiz olduklarını bilmediklerini söylemişlerdir. Aşağıda verilen alıntılar açıklamayı desteklemektedir.

"Sonuç 1 gibi ancak bu ifadeyi hep belirsizlik olarak veriyoruz $\left(L_{5}\right) . "$

"Limit konusunda bilgilerim dâhilinde $1^{\infty}$ belirsiz bir ifade. Ancak neden belirsiz olduğunu bilmiyorum. Bu ifadeyi belirsiz olarak bilmeseydim sonuca 1 diyebilirdim. $\left(L_{6}\right)$."

Bu açıklamalardan anlaşılacağı üzere, lisede görev yapan her iki öğretmenin de bu gösterimi ezbere bildiği ve derslerinde bu gösterimi belirsiz olarak verdikleri için belirsiz dedikleri aşikârdır. Bu gösterimin belirsiz olduğunu hatırlamayan üç öğretmen $\left(L_{2}, L_{4}, O_{4}\right), 1$ cevabını vererek gerekçe olarak "1'in tüm kuvvetleri 1'dir" açıklamasını yapmışlardır. Buradan katılımcıların kuvvetteki sonsuzun sonuca etki etmediğini düşündükleri ve sonsuzu bir sayı olarak algıladıkları söylenebilir. $L_{3}$ öğretmeni de belirsiz ve tanımsız kavramlarını eş anlamlı olarak 
düşünerek bu gösterimin hem belirsiz hem de tanımsız olduğunu söylemiş ancak gerekçesini ifade edememiştir.

$\frac{0}{0}$ ve $\frac{\infty}{\infty}$ belirsizlikleri ile ilgili öğretmenlerin açıklamaları incelendiğinde, öğretmenlerin çoğunun bu sembolik gösterimler için "belirsizliği ifade eder" şeklinde doğru cevap verdikleri görülmektedir. Bu belirsizlik durumlarını temsil eden iki gösterim arasında da özellikle $\frac{\infty}{\infty}$ belirsizlik durumuna daha fazla öğretmen doğru cevap verebilmiştir. Bu gösterimlerin belirsizlik durumunu temsil etmesinin altında yatan sebepler incelendiğinde, bazı öğretmenler doğru sayılabilecek açıklamalarda bulunurken, bazıları ya mantıklı olmayan ya da yüzeysel açıklamalarda bulunmuşlardır.

Şekil 5'te doğru sayılabilecek açıklamalarla ilgili iki öğretmenden alıntıya yer verilmiştir.

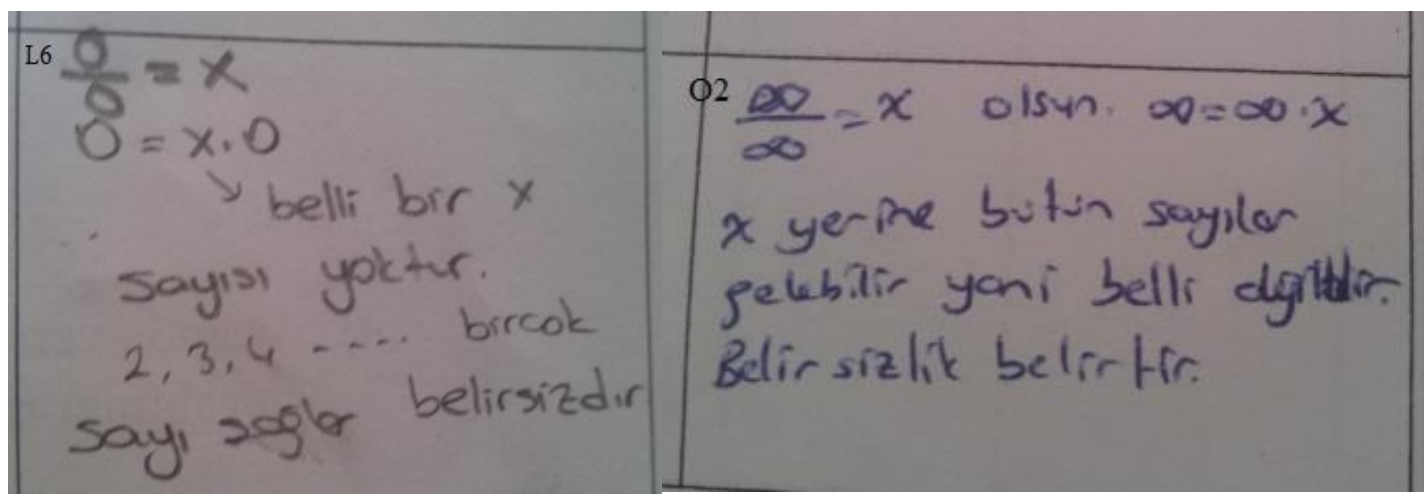

Şekil 5. L6 $\operatorname{nın} \frac{0}{0}, O_{2}$, nin $\quad \frac{\infty}{\infty}$ gösteriminin belirsiz olduğuna ilişkin cevabı

Şekil 5 incelendiğinde, L' $\operatorname{n} ı n \frac{0}{0}$ gösteriminin belirsizlik durumunun altında yatan mantıksal gerekçeyi gösterdiği açıkça görülmektedir. Zangari (1994) de bu gösterimin belirsiz olmasının nedenini aynı gerekçe ile ifade etmiş ve şu şekilde sunmuştur:

$x=\frac{y}{z} \quad\left(x=\frac{0}{0}\right) \rightarrow \frac{y}{z}=\frac{0}{0} \rightarrow 0 . z=0 . y$ Bu ifade $z$ ve $y^{\prime}$ nin sonsuz değeri için doğru olduğundan z ve y yerine gelebilecek değerler belli değildir. Bu nedenle bu gösterim belirsizdir.

Diğer açıklamalar incelendiğinde $\mathrm{O}_{6}, \quad \frac{\infty}{\infty}$ sembolik gösteriminin belirsiz olduğunu, "Belirsizlik vardır. iki sonsuzun eşit olduğunu bilmiyoruz ki " şeklinde farklı bir açıklama yaparak sonsuzu sayı olarak algılamıştır. Yanlış cevap veren öğretmenlerin açıklamaları incelendiğinde, katılımcıların $\frac{0}{0}$ ' $\iota$ tanımsız olarak ifade ettikleri görülmüştür. Bu cevabın gerekçesini açıklayan iki öğretmen ise, bu gösterime neden tanımsız dediklerini şu şekilde açıklamışlardır.

'Paydada sıfır var. Ayrıca olmayan şeyler arasında bölme işlemi yapılmaz $\left(\mathrm{O}_{4}\right)$ '

'Sıfırın içinde sıfır aranmaz. $\left(\mathrm{O}_{6}\right)^{\prime}$

Bu alıntılara göre, öğretmenler bu gösterimin mantıksal gerekçesini ifade edememişler ve ezbere dayalı açıklamalara yer vermişlerdir. 


\subsection{Tanımsızlık Kavramının Tanımı ve Tanımsızlık Kavramını Temsil Eden Gösterimlere İlişkin Bulgular}

Tablo 8

Matematik Öğretmenlerinin Tanımsızlık Kavramının Tanımına ilişkin Verdikleri Cevaplar

\begin{tabular}{|c|c|c|}
\hline Tanımsızlık & ÖK & Örnek Açıklamalar \\
\hline $\begin{array}{l}\text { Tanımsız } \\
\text { Değer }\end{array}$ & $\mathrm{L}_{6}, \mathrm{O}_{5}, \mathrm{O}_{7}$ & $\begin{array}{l}\text { Sayı/Sıfır tanımsızdır. } 5 / 0=x \text { ifadesinde içler dışlar çarpımı } \\
\text { yaptığımızda } 0 . x=5 \text { olur ki bunu sağlayan bir sayı değeri } \\
\text { tanımlanamaz }\left(\mathrm{L}_{6}\right) \\
\text { Sıfırdan farklı bir sayının sıfıra bölümünde değeri tanımlı } \\
\text { olmaz }\left(O_{7}\right)\end{array}$ \\
\hline $\begin{array}{l}\text { Tanımsız } \\
\text { Durum }\end{array}$ & $\begin{array}{l}\mathrm{L}_{1}, \mathrm{~L}_{2}, \mathrm{~L}_{4} \\
\mathrm{~L}_{5}, \mathrm{O}_{1}, \mathrm{O}_{2}, \mathrm{O}_{3}, \mathrm{O}_{4} \\
\mathrm{O}_{6}, \mathrm{O}_{7}\end{array}$ & $\begin{array}{l}\text { Tanımsızlık mantığın doğru fakat durumu tanımlı kılacak } \\
\text { uygun bir sonucun olmadığı zaman ortaya çıkar. Duruma } \\
\text { bağlıdır }\left(O_{1}\right) \\
\text { Tanımlanamayan durumlardır. Belirlenen koşulları } \\
\text { sağlamaz }\left(O_{7}\right)\end{array}$ \\
\hline Boş & $\mathrm{L}_{3}$ & Tanımı yok $\left(L_{3}\right)$ \\
\hline
\end{tabular}

ÖK: Öğretmen Kodları

Tablo 8'deki bulgulara göre, öğretmenler tanımsızlık kavramının anlamını tanımsız değer ve tanımsız durum olarak ifade etmişlerdir. Bazı öğretmenler, sıfırdan farklı bir sayının sıfıra bölünmesi durumunu örnek vererek açıklamışlardır. Bu örneği de şu şekilde açıklamışlardır: $\frac{a}{0^{\prime}}$ $a \neq 0, \frac{a}{0}=x$ ifadesinde $a=0$ değeri alabilir. Bu durum a'nın sıfırdan farklı olmasıyla çeliştiğinden bu ifade tanımlanamayan değerdir). Diğer taraftan, bazı öğretmenler de tanımsızlığı, tanımlamayan durum olarak ifade etmişler ancak bu tanımı detaylı olarak açıklayamamışlardır. Bu tanımı, Özmantar ve Bozkurt (2013), matematiksel yapının (kavram, işlem, ilişki vb.) tanımında belirlenen şartları sağlamayan tanımsızlık türü olarak ifade etmiştir. 'Örneğin $x^{2}+$ $1=0$ denkleminin çözümü gerçek sayılarda tanımlı değildir. Ancak karmaşık sayılar kümesi esas alınırsa çözülebilir. Dolayısıyla tanımsızlık durumu, ele alınan kavram ve yapılar özelinde değerlendirilmelidir' şeklinde belirtmişlerdir.

Tablo 9

Matematik Öğretmenlerinin Tanımsızlık Kavramını Temsil Eden Durumlara Iilişkin Verdikleri Cevaplar

\begin{tabular}{|c|c|c|c|c|c|}
\hline$\underset{\mathbf{N}}{\mathrm{N}}$ & $\begin{array}{l}\text { Sembolik } \\
\text { Gösterimler }\end{array}$ & Doğru & $\begin{array}{l}\text { Kısmen } \\
\text { Doğru }\end{array}$ & Yanlış & Boş \\
\hline క & $\frac{1}{0}$ & $\begin{array}{l}\mathrm{L}_{1}{ }^{*}, \mathrm{~L}_{2}{ }^{*}, \mathrm{~L}_{4} \mathrm{~L}_{5}, \mathrm{~L}_{6}{ }^{*}, \mathrm{O}_{1}, \mathrm{O}_{2}, \mathrm{O}_{3}, \mathrm{O}_{5}, \mathrm{O}_{6}{ }^{*}, \\
\mathrm{O}_{7}{ }^{*}\end{array}$ & $L_{3}$ & $\mathrm{O}_{4}{ }^{*}$ & \\
\hline
\end{tabular}

(*) simgesi olan katılımcılar, verdiği cevabın altında yatan nedene ilişkin açıklama yaparken, (*) simgesi olmayan katılımcılar, verdiği cevabın altında yatan nedene ilişkin açıklama yapmamıştır.

Tablo 9'a göre, öğretmenlerin hemen hemen tamamı, $\frac{1}{0}$ gösteriminin tanımsız olduğunu ifade ederek doğru cevap vermişlerdir. Bu öğretmenlerden dördü, bu gösterimin neden tanımsız olduğunun altında yatan mantıksal gerekçe hakkında detaylı görüş bildirmemişlerdir. Aşağıda verilen alıntılar da bu açıklamayı en iyi şekilde örneklendirmektedir. 
"Çünkü sonuç tanımlanamaz $\left(L_{1}\right) . "$

"Paydadaki sıfır bölümü tanımsız yapar. Paydada sıfır olamaz. O yüzden tanımlanamaz $\left(L_{2}\right) . "$

"1'in O'a bölümü yapılamaz. Yani paydada sıfır olamaz $\left(\mathrm{O}_{4}\right)$. "

"1'in içinde sıfır aranmaz $\left(O_{6}\right) . "$

Yukarıdaki alıntılardan da anlaşılacağı üzere, öğretmenlerin gerekçeleri yüzeysel olup, kurala dayalı ezber bilgi içeren açıklamalardır. Yapılan görüşmelerde $L_{3}$ öğretmeni de bu ifadenin hem belirsiz hem de tanımsız olduğunu söyleyerek tanımsızlık ve belirsizlik durumlarını eş anlamlı kullanmıştır. Diğer taraftan $\mathrm{L}_{6}$ ve $\mathrm{O}_{7}$ ise, bu ifadenin neden tanımsız olduğunu ayrıntılı bir şekilde açıklamışlar ve yazılı olarak da ifade etmişlerdir. Bununla ilgili olarak $\mathrm{O}_{7}$ 'nin yazılı cevabı Şekil 6'da aynen verilmiştir.

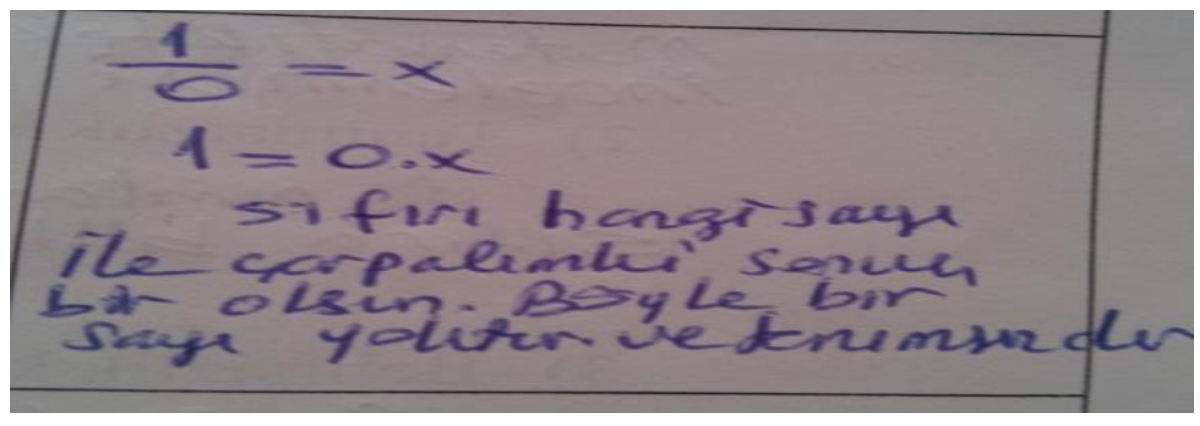

Şekil 6. O $O_{7}$ nin $\frac{1}{0}$ gösteriminin belirsiz olduğuna ilişkin cevabı

Şekil 6'ya göre, $\mathrm{O}_{7}$, verilen ifadeye $x$ değişkeni vermiştir. İçler dışlar çarpımı yaptığı zaman 1=0.x eşitliğinden sıfır sayısı ile hangi sayı çarpılırsa çarpılsın sonucun 1'e eşit olamayacağını doğru bir şekilde göstermiştir. Özmantar ve Bozkurt (2013) da, matematikte sıfırdan farklı bir sayının sıfır ile bölümünün tanımsız olduğunu benzer şekilde şu şekilde ifade etmiştir: $a \neq 0$ olmak üzere $\frac{a}{0}$ tanımlı olsaydı $\frac{a}{0}=x$ olacak şekilde bir $x$ reel sayısı bulunurdu. Bu durumda a=0. $x$, yani a $=0$ olurdu. Bu da $a \neq 0$ oluşuyla çelişir. Bu çelişki de bu gösterimin bir sayı değerine karşıık gelemeyeceğini diğer bir ifadeyle tanımlanamayacağını söyler.

\section{SONUÇLAR, TARTIŞMA VE ÖNERILER}

Bu çalışmada, öğretmenlerin matematikte birbirine çok karıştırılan sonsuzluk, belirsizlik ve tanımsızlık kavramlarına ilişkin öğretimsel açıklamaları incelenmiştir. Bu amaç doğrultusunda, bu üç kavramın tanımları ve bu kavramları temsil eden sembolik gösterimler hakkında öğretmenlerin görüşleri alınmıştır.

Sonsuzluk kavramına ilişkin öğretmenlerin açıklamaları incelendiğinde, öğretmenlerin çoğunun sonsuzluk kavramını "sembol, sonsuz elemanlardan oluşan küme" gibi obje (nesne) olarak, geriye kalan öğretmenlerin de bir süreç olarak algıladıkları tespit edilmiştir. Tall ve Schwarzenberger (1978) çalışmasında, sonsuzluğu bir nesne (sembol, çok büyük bir sayı) olarak tanımlayan öğrencilerin olduğunu ifade etmişlerdir. Aynı şekilde, bu sonuç, Maria ve diğerleri (2009)'nin çalışma sonuçlarıyla paralellik göstermektedir. Maria ve diğerleri, öğretmenlerin \%27.9'unun sonsuzluk kavramını bir obje olarak, \%72.1'inin de bir süreç olarak ifade ettiklerini 
ortaya çıkarmışlardır. Yapılan başka bir çalışmada da ortaokul öğrencilerinin sonsuzluk kavramını sonu olmayan, bitmeyen ve devam eden bir süreç olarak algıladıkları görülmüştür (Bozkuş, Toluk-Uçar, \& Çetin, 2015).

Sonsuzluğu temsil eden sembolik gösterimlere ilişkin sonuçlar incelendiğinde, ulaşılan önemli sonuçlardan biri, öğretmenlerin çoğunun sonsuzluğu temsil eden gösterimleri tanımasıdır. Özellikle de tüm öğretmenler, $\infty^{n}$ gösteriminin sonsuz olduğunu bilmişlerdir. Sonsuzluğu temsil eden diğer gösterimlerde hatalı cevap veren öğretmenlerden bazıları, sonsuz kavramı yerine belirsiz ya da 1 cevabını vermişlerdir. Literatürde de öğretmen adaylarının sonsuzluk kavramı yerine belirsizliği kullandıkları çalışmalara rastlamak mümkündür (Çelik \& Akşan, 2013; Kanbolat, 2010). Öğretmenlerin, bu gösterimlerin neden sonsuzluk kavramını temsil ettiğine ilişkin gerekçeleri incelendiğinde, çoğu öğretmen, sonsuzluğun büyüklüğüne vurgu yapmışlardır. Örneğin $(\infty-1)$ ifadesinde sonsuzun büyüklüğünden dolayı 1 'in etki etmediğini dile getirmişlerdir.

Belirsizliğin tanımı ile ilgili bulgular dikkate alındığında, öğretmenlerin çoğunun belirsizliği "belirsiz değer" olarak algıladıkları ortaya çıkmıştır. Bir öğretmen $\left(\mathrm{O}_{7}\right)$ de matematikte limit konusunda karşılaşılan belirsiz formlarla ilişkilendirerek belirsizliği anlamlandırmaya çalışmıştır. Belirsizlik kavramını temsil eden gösterimler ele alındığında öğretmenlerin en çok $\left(\infty^{0}\right)$ ve $(\infty-\infty)$ gösterimlerini tanımada zorlandıkları, en az $\left(\frac{\infty}{\infty}\right)$ gösteriminde zorlandıkları ortaya çıkmıştır. Bunun sebebi olarak, öğretmenlerin $\left(\frac{\infty}{\infty}\right)$ gösterimiyle daha sık karşılaşmaları gösterilebilir. Hatalı cevap veren öğretmenlerin cevapları incelendiğinde, dikkat çeken sonuçlardan biri, öğretmenlerin belirsizlik kavramı yerine sonsuzluk ve tanımsızlık kavramlarını kullanmalarıdır. Kanbolat (2010) çalışmasında bu üç kavramın birbiri yerine kullanıldığını ifade etmiştir. Jaffar ve Dindyal (2011) çalışmasında, öğrencilerin $\frac{0}{0}$ belirsizliğini, tanımsız olarak ifade ettiklerini belirtmişlerdir. Öğretmenlerin, belirsizliği tanımsız olarak düşünmelerinin sebeplerinden biri, tanımsız değerde paydanın sıfır olması olabilir. Nair (2010), öğrencilerin $\frac{0}{0}$ ile $\frac{b}{0} b \neq 0$ gösterimlerini benzer anlam yüklediklerini belirtmiştir. Sonsuz ile tanımsız kavramlarının eş anlamlı olarak kullanılmasının sebeplerinden biri, öğretmenlerin derslerinde $\frac{a}{0}$ ifadesini ortaokulda tanımsız, lisede sonsuz olarak ifade etmeleri olabilir. Dolayısıyla öğretmenler $\infty=$ tanımsız olarak düşünmekte ve eş anlamlı olarak kullanmaktadır.

Çalışmanın önemli sonuçlarından bir diğeri de, bazı öğretmenlerin sonsuzu sayı olarak algılamalarıdır. Çünkü elde edilen bulgularda, bazı öğretmenler sayılar için geçerli olan kuralları $\left(\infty^{0}=1,0 . \infty=0,1^{\infty}=1\right)$ şeklinde uygulamış ve sonsuzu sayı olarak düşünerek işlem yapmışlardır. Literatürde de bu sonuçları destekleyen çalışmalara rastlamak mümkündür (Çelik \& Akşan, 2013; Monaghan, 1986, 2001; Nesin, 2002; Özmantar, 2013; Singer \& Voica, 2003). Sonsuzun sayı olarak algılanmasının sebebi, öğretmenlerin çoğunun sonsuzu nesne (sembol vb.) olarak algılamaları gösterilebilir. Nesin (2002) de benzer şekilde sonsuzun sayı olarak algılanmasının nedenlerinin başında sonsuz için kullanılan sembolü göstermektedir.

Tanımsızlık kavramına ilişkin sonuçlar incelendiğinde, öğretmenlerin çoğunun tanımsızlığı yüzeysel olarak açıkladıkları ve tanımsızlığı "tanımsız durum" olarak ifade ettikleri görülmüştür. Sembolik gösterimlerde ise öğretmenlerin nerdeyse tamamının $\frac{1}{0}$ olan sembolik gösterimi tanıdıkları görülmektedir. Bazı öğretmenler bu gösterimin neden tanımsız olduğunu yüzeysel ifade ederken, bazı öğretmenler de detaylı açıklama yapmışlardır. Öğretmenler, tanımsız olmasının altında yatan mantıksal gerekçe olarak Özmantar ve Bozkurt (2013)'un açıklamasını kullanmışlardır. Bu sonuçlar neticesinde, çalışmada şu önerilere yer verilmiştir: 
Bu çalışmada öğretmenlerin çoğunun sonsuzluk, belirsizlik ve tanımsızlık durumlarını temsil eden tüm gösterimlere doğru cevap veremedikleri görülmüştür. Çoğu öğretmen, bu gösterimlerin anlamları altında yatan mantıksal gerekçe hakkında ya yüzeysel açıklama yapmış ya da herhangi bir açıklamada bulunmamışlardır. Bu nedenle, hizmet öncesi lisans derslerinde öğretim üyeleri tarafından alan derslerinde bu kavramların asıl anlamları üzerinde durulabilir. Ayrıca öğretmenlerin bu kavramların anlamları ve bu kavramları temsil eden gösterimlere ilişkin alan bilgilerinin gelişimine yönelik çalışmalar yapılabilir.

Bu çalışma öğretmenler ile yürütülmüştür. Benzer çalışmalar öğretmen adayları ve öğretmenlerle yürütülerek karşılaştırmalı çalışmalara yer verilebilir.

Bu çalışmada sonsuzluk, belirsizlik ve tanımsızlık kavramlarının tamamı ele alındığından bu kavramların ayrı anlamları (örneğin tanımsızlık çeşitleri) incelenememiştir. Bu alanda çalışma yapacak olan araştırmacıların, bu kavramlardan her birine ilişkin detaylı çalışma yaparak sonsuzluk, belirsizlik ve tanımsızlık kavramlarını ayrı incelemeleri önerilebilir.

\section{KAYNAKLAR}

Alev, M., Beler, A., \& Çakır, S. (1986). Thomas matematik. Ankara: Ayrım Yayınları.

Aztekin, S. (2008). Farklı yaş gruplarındaki öğrencilerde yapılanmış sonsuzluk kavramlarının araştırılması. (Yayımlanmamış doktora tezi). Gazi Üniversitesi Eğitim Bölümleri Enstitüsü, Ankara.

Aztekin, S., Arikan, A., \& Sriraman, B. (2010). The constructs of phd students about infinity: an application of repertory grids. The Montana Mathematics Enthusiast, 7(1), 149- 174.

Balcı, M. (2010). Genel matematik (6 Baskı). Balcı Yayınları

Baştürk, S. \& Dönmez, G. (2011). Matematik öğretmen adaylarının limit ve süreklilik konusuyla ilgili kavram yanılgıları. Necatibey Eğitim Fakültesi Elektronik Fen ve Matematik Eğitimi Dergisi (EFMED), 5(1), 225-249.

Bozkuş, F., Toluk-Uçar, Z., \& Çetin, i. (2015). Ortaokul öğrencilerinin sonsuzluğu kavrayışları. Türk Bilgisayar ve Matematik Eğitimi Dergisi, 6(3), 506-531.

Cankoy, O. (2010). Mathematics teachers' topic-specific pedagogical content knowledge in the context of teaching $\mathrm{a}^{\circ}, 0$ ! and a/0. Kuram ve Uygulamada Eğitim Bilimleri, 10(2), 749-769.

Crespo, S. \& Cynthia, N. (2006). Challenging preservice teachers' mathematical understanding: the case of division by zero. School Science \& Mathematics, 106(2), 84-98.

Çekmez, E. (2016). Using menelaus' theorem and dynamic mathematics software to convey the meanings of indeterminate forms to students. Academic Journals, Educational Research and Reviews, 11(6), 277-287.

Çelik, D. \& Akşan, E. (2013). Matematik öğretmeni adaylarının sonsuzluk, belirsizlik ve tanımsızlık kavramlarına ilişkin anlamaları. Necatibey Eğitim Fakültesi Elektronik Fen ve Matematik Eğitimi Dergisi (EFMED), 7(2), 166-190.

Ervynck, G. (1994). Students' conceptions of infinity in the calculus. problems, resources, and issues in mathematics undergraduate studies. PRIMUS, 4(1), 84-96.

Gökkurt, B. (2014). Ortaokul matematik öğretmenlerinin geometrik cisimler konusuna ilişkin pedagojik alan bilgilerinin incelenmesi. (Yayımlanmamış Doktora Tezi). Atatürk Üniversitesi Eğitim Bilimleri Enstitüsü, Erzurum. 
Gökkurt, B., Şahin, Ö., \& Soylu, Y. (2012). Matematik öğretmenlerinin matematiksel alan bilgileri ile pedagojik alan bilgileri arasındaki ilişkinin incelenmesi. The Journal of Academic Social Science Studies, 5(8),997-1012.

Jaffar, S. M. \& Dindyal, J. (2011). Language-related misconceptions in the study of limits. In J. Clark, B. Kissane, J. Mousley, T. Spencer, \& S. Thornton (Eds.), Proceedings of the 34th annual conference of the Mathematics Education Research Group of Australasia and the 23rd biennial conference of the Australian Association of Mathematics Teachers, Alice Springs, pp. 390-397). Adelaide, SA: Aamt \& Merga.

Joshua, C. (2012). Pre-service secondary mathematics teachers making sense of definitions of functions. Mathematics Teacher Education and Development, 14(1), 27-40.

Juter, K. (2005). Student's attitudes to mathematics and performance in limits of functions. Mathematical Education Research Journal, 17(2), 91-110.

Kadıoğlu E. \& Kamali M. (2009). Genel matematik (4. Baskı). Erzurum: Kültür Eğitim Vakfı Yayınevi.

Kanbolat, O. (2010). Bazı matematiksel kavramlarla ilgili epistemolojik engeller. (Yayımlanmamış yüksek lisans tezi). Karadeniz Teknik Üniversitesi, Fen Bilimleri Enstitüsü, Trabzon.

Kim, D., J., Sfard, A., \& Ferrini-Mundy, J. (2005). Students' colloquial and mathematical discourses on infinity and limit. Paper presented at the Conference of the International Group fort he Psychology of Mathematics Education (29th, Melbourne, Australia, Jul 10$15,2005), 3,201-208$.

Konyalığlu, A. C. (2015). Matematik alan eğitimi test kitabı (1.Baskı). Erzurum: Ertual Akademi Yayıncılık.

Konyalıoğlu, A.C. \& Gedik, S. D. (2015). Matematik öğretiminde hata temelli aktiviteler (1.Baskı).Erzurum: Ertual Akademi Yayıncılık.

Maria, K., Thanasia, M., Katerina, K., Constantinos, C., \& George, P. (2009). Teachers' perceptions about infinity: a processor an object?.Paper session presented at the meeting of Proceedings of CERME, 6, Lyon, France.

Miles, M. B. \& Huberman, A. M. (1994). Qualitative data analysis: An expanded sourcebook. (Second Edition). California: SAGE Publications.

Monaghan, J. D. (1986). Adolescents' understanding of limits and infinity. (Unpublished doctoral thesis). University of Warwick.

Monaghan, J. D. (2001). Young peoples' ideas of infinity. Educational Studies in Mathematics, $48(2-3), 239-257$.

Nair, G.S. (2010). College students' concept images of asymptotes, limits, and continuity of rational functions. (Unpublished doctoral thesis). The Ohio State University.

Narlı, S. \& Narlı, P. (2013). Sonsuz sayı kümeleri ışığında ilköğretim öğrencilerinin sonsuzluk algı ve yanılgılarının belirlenmesi. Buca Eğitim Fakültesi Dergisi, 33, 122-133.

Özmantar, M. F. (2013). Sonsuzluk kavramı: Tarihsel gelişimi, öğrenci zorlukları ve çözüm önerileri. M. F. Özmantar, E. Bingölbali, \& H. Akkoç (Edt.), Matematiksel kavram yanılgıları ve çözüm önerileri (s.151-180) (3. Baskı). Ankara: Pegem Akademi. 
Özmantar, M. F. \& Bozkurt, A. (2013). Tanımsızlık ve belirsizlik: kavramsal ve geometrik bir inceleme. I.Ö. Zembat, M. F. Özmantar, E. Bingölbali, Şandır, H. , \& A. Delice (Edt.), Tanımları ve tarihsel gelişimleriyle matematiksel kavramlar (ss. 437-461) (1. Baskı). Ankara: Pegem Akademi.

Reys, R. E. \& Grouws, D. A (1975). Division involving zero: Some revealing thoughts from interviewing children. School Science and Mathematics, 78, 593-605.

Shirvani H. (2015). Pre-service elementary teachers' mathematics content knowledge: a predictor of sixth graders' mathematics performance. International Journal of Instruction, 8(1), 133-142.

Singer, M. \& Voica, C. (2003). Perception of Infinity: Does it Really Help in Problem Solving?. The Mathematics Education into the 21st Century Project Proceedings of the International Conference.

Singer, M. \& Voica, C. (2007). Children's perceptions on infinity: Could They Be Structured? http://www.mathematik.uni-dortmund.de/ erme/CERME5b/WG3.pdf adresinden 10 Eylül 2016 tarihinde indirilmiştir.

Tall, D. O. \& Schwarzenberger, R. L. E. (1978). Conflicts in the learning of real numbers and limits. Mathematics teaching, 82, 44-49.

Yıldııım, A. \& Şimşek, H. (2013). Sosyal bilimlerde nitel araştırma yöntemleri (8. Baskı). Ankara: Seçkin Yayıncılık.

Zangari, M (1994) Zeno, zero and indeterminate forms: instants in the logic of motion. Australasian Journal of Philosophy, 72(2), 187-204.

Zikre, N. M. \& Eu, L.K. (2016) Malaysian mathematics teachers' beliefs about the nature of teaching and learning. The Malaysian Online Journal of Educational Science, 4(1), 21-29. 


\section{SUMMARY}

The notion of infinity constitutes an intuitively contradictory concept that has long occupied many philosophers and mathematicians. Since infinity which has been the focal point for centuries is one of the fundamental concepts for many mathematical concepts such as number line, it is inevitable to clarify this concept. Furthermore, the fact that the definitions in mathematics are important also encourages us to do so. The concept of infinity may be seen as a mathematical idea that causes various obstacles to learners due to the duality of its meaning, as an object and as a process. Let us start with a simple question to define the concept of infinity. Is the concept of infinity " $\infty$ " a number? Let us try to answer the question with the following sentences. When $\mathrm{x}$ gets closer from positive numbers to zero, $\frac{1}{x}$ goes to $+\infty$; when $x$ gets closer from negative numbers to zero, $\frac{1}{x}$ goes to $-\infty$; symbol $\infty$ is read as "infinity", however, it does not represent any real number. $+\infty$ and $-\infty$ are not numbers but only symbols. $+\infty$ is considered to be a "magnitude" which is larger than any positive number; $-\infty$ is considered to be a "magnitude" which is smaller than any negative number. After this explanation, it is understood that using "infinity" as a number is incorrect. Although $+\infty$ and $-\infty$ are not numbers, operations related to them are defined. For example, $a \times(+\infty)=+\infty$ (if $a>0$ ). The expressions given for the ease of presentation such as a $x(+\infty)=+\infty$ (if $a>0$ ) are actually the result of a limit operation. Some operations related to $+\infty$ and $-\infty$ cannot have a certain single value. These are called uncertainty. When the limit of an $f$ function at $x=a$ point is investigated, expressions such as $\frac{0}{0}, \frac{\infty}{\infty}, \infty-\infty, 0 . \infty, 0^{0}, \infty^{0}, 1^{\infty}$ which are called uncertain shapes are encountered.

As the relationships between the concepts of "infinity" and "indeterminate" are described in this way, the concept of "Undefined", which is another subject of this study, can be explained as follows. The most important point that must be taken into consideration when performing an operation with numbers is that a non-zero number is indivisible with zero. In mathematics, when a non-zero number is divided with zero, the result is unidentifiable. Because, when $a \neq 0$, if $\frac{a}{0}$ was identifiable, there should be a real number $\mathrm{c}$ as the result of $\frac{a}{0}=\mathrm{c}$. In this case, $\mathrm{a}=0 . \mathrm{c}$, in other words, $\mathrm{a}=0$. This contradicts to the precondition of $a \neq 0$. In that case, it is obvious that dividing a non-zero number with zero is unidentifiable. An extensive review of the literature revealed that most of the various grade level students have difficulty in understanding the concepts of infinity and undefined. A review of literature also showed that there is limited studies conducted about the concept of indeterminate. When the relevant literature is reviewed, it attracts attention that the studies on these concepts were usually carried out with students and preservice teachers. There is a limited number of studies investigating the understanding of teachers of these concepts. However, investigating the knowledge of teachers that play an important role in person in teaching about these concepts is important. Accordingly, the understanding of mathematics teachers of the concepts of infinity, indeterminate and undefined was investigated in detail in the present study. 13 mathematics teachers working at secondary and high schools in the 2015-2016 academic year were included in the study. A form consisting of two parts was applied to teachers. In the first part of the form, there are three questions about what infinity, indeterminate and undefined concepts are, and in the second part there are nine questions representing the concepts of infinity, indeterminate and undefined. Five situations representing the concepts of indeterminate and infinity that teachers or preservice teachers frequently experience were added to the second part by the researcher. The case study method based on the qualitative research approach was used in the study. The interview form was used as a data collection tool. Qualitative data analysis techniques were used to analyze the data. In this context, the descriptive analysis technique was used. At the end of the study, it was found out that some teachers used the concepts of infinity, indeterminate and undefined instead of one another. Furthermore, it was observed that the rationale of some teachers of symbolic situations was affected by the rules they had previously learnt. 